\title{
Clostridium arbusti sp. nov., an anaerobic bacterium isolated from pear orchard soil
}

Correspondence Young-Hyo Chang yhchang@kribb.re.kr

\author{
Min Young Jung, ${ }^{1,2}$ In-Soon Park, ${ }^{1}$ Wonyong Kim, ${ }^{2}$ Hong Lim Kim, ${ }^{3}$ \\ Woon Kee Paek ${ }^{4}$ and Young-Hyo Chang ${ }^{1}$
}

\author{
${ }^{1}$ Korean Collection for Type Cultures, Biological Resource Center, KRIBB, 52 Oeundong, \\ Daejeon 305-806, Republic of Korea \\ ${ }^{2}$ Department of Microbiology, College of Medicine, Chung-Ang University, 221 Heukseok-dong, \\ Dongjak-ku, Seoul 156-756, Republic of Korea \\ ${ }^{3}$ Namhae Sub-Station, National Horticultural Research Institute, RDA, Namhae, 668-812, \\ Republic of Korea \\ ${ }^{4}$ National Science Museum, 32-2 Guseong-dong, Yuseong-gu, Daejeon 305-705, \\ Republic of Korea
}

\begin{abstract}
An obligately anaerobic, Gram-positive, spore-forming bacterial strain, designated SL206 ${ }^{\top}$, was isolated from pear orchard soils. Strain SL206 ${ }^{\top}$ cells were straight or slightly curved rods, with motility by peritrichate flagella. Cell walls contained meso-diaminopimelic acid; wall sugars were glucose, rhamnose and mannose. The major fatty acids were $C_{16: 0}, C_{18: 1} \omega 9 c$ and summed feature 10 (containing $\mathrm{C}_{18: 1} \omega 11 \mathrm{c} / 9 \mathrm{t} / 6 t$ ). API 20A reactions were negative for oxidase, catalase and acid production from L-rhamnose, sucrose, trehalose, D-xylose, melezitose, salicin and Dsorbitol, and positive for acid production from D-glucose, sucrose, maltose, D-mannose and raffinose. Glucose was fermented to acetate, butyrate, $\mathrm{CO}_{2}, \mathrm{H}_{2}$ and ethanol in culture. The $\mathrm{G}+\mathrm{C}$ content of the genomic DNA was $31.1 \mathrm{~mol} \%$. Based on comparative 16S rRNA gene sequence analysis, the isolate belonged to the genus Clostridium and formed a clade with Clostridium pasteurianum. The species most closely related to strain SL206 ${ }^{\top}$ were C. pasteurianum (98.6\% similarity) and Clostridium acidisoli (97.8\% similarity). In DNA-DNA relatedness studies, the isolate had $59.5 \%$ relatedness with $C$. pasteurianum and thus represented a unique species. On the basis of these studies, strain SL206 ${ }^{\top}\left(=\mathrm{KCTC} 5449^{\top}=\mathrm{JCM} 14858^{\top}\right)$ is proposed to represent the type strain of a novel species, Clostridium arbusti sp. nov.
\end{abstract}

The genus Clostridium is a large and phenotypically heterogeneous taxon, currently comprising more than 190 species (Wiegel et al., 2006). The DNA of these anaerobic bacteria are classified as belonging to three major groups (Wiegel et al., 2006): the low-G + C Gram-positive bacteria, the Clostridium coccoides-Eubacterium rectale group (cluster XIVa), and the Clostridium leptum group (cluster IV). The species within this genus are divided into several cluster groups based on $16 \mathrm{~S}$ rRNA gene sequences (Collins et al., 1994). Cluster I, which includes the type species of the genus, Clostridium butyricum, is the largest of the clostridial groups, and members of this group exhibit similarity values above $90 \%$ despite exhibiting a range of saccharolytic, proteolytic, psychrophilic, mesophilic and thermophilic phenotypes. Some of the strains within cluster I have been isolated and described as novel microorganisms obtained from soil or sediments (Jeong et al.,

The GenBank/EMBL/DDBJ accession number for the 16S rRNA gene sequence of strain SL206 ${ }^{\top}$ is EU816420.
2004; Kim et al., 2006, 2007; Lee et al., 2007). In this study, we report the taxonomic description of a strictly anaerobic bacterium within cluster I, designated strain SL206 ${ }^{\mathrm{T}}$.

Strain SL206 ${ }^{\mathrm{T}}$ was isolated from soil samples $(30 \mathrm{~cm}$ depth) collected from a pear orchard in Daejeon, Republic of Korea. The samples were serially diluted in $0.85 \%$ (w/v) saline solution, spread onto Reinforced Clostridial Medium (RCM; Difco) that was heated at $80{ }^{\circ} \mathrm{C}$ for $10 \mathrm{~min}$, and incubated at $30{ }^{\circ} \mathrm{C}$ under anaerobic conditions (Forma Anaerobic System; Thermo Fisher Scientific) using a gas phase of $\mathrm{N}_{2} / \mathrm{H}_{2} / \mathrm{CO}_{2}$ $\left(88: 7: 5 \%\right.$, v/v). Strain SL206 ${ }^{\mathrm{T}}$ was subcultured several times to obtain a pure culture on agar plates. The reference strains used in the study were Clostridium pasteurianum KCTC $1674^{\mathrm{T}}$ and Clostridium acidisoli KCTC $5384^{\mathrm{T}}$. Strains were cultured routinely on RCM in Hungate tubes (Bellco) under anaerobic conditions and stored at $-80{ }^{\circ} \mathrm{C}$ as skim milk (Difco) suspensions $(10 \%, \mathrm{w} / \mathrm{v})$.

To determine the phenotypic characteristics of strain SL206 ${ }^{\mathrm{T}}$, cells were grown on RCM agar at $37{ }^{\circ} \mathrm{C}$ for $48 \mathrm{~h}$. 
Gram staining (Gram stain kit; Difco) and the $\mathrm{KOH}$ test were carried out as described previously (Chang et al., 2008). Cell morphology and flagellation were examined by phasecontrast microscopy (Nikon 80i) and transmission electron microscopy (H-7600, Hitachi). Catalase activity was detected by placing drops of $3 \%(\mathrm{v} / \mathrm{v}) \mathrm{H}_{2} \mathrm{O}_{2}$ onto plategrown cultures and observing the production of oxygen bubbles. The presence of oxidase activity was determined by using an Oxy-swab (bioMérieux). Various biochemical properties were determined by using the API 20A, 32A and ZYM strips (bioMérieux) according to the manufacturer's instructions. The $\mathrm{pH}$ range for growth was determined by growing cells in $500 \mathrm{ml}$ bottles (Corning) containing $250 \mathrm{ml} \mathrm{RCM}$ broth at $\mathrm{pH} 4-9$ in 0.5-unit increments. Broths were buffered with $\mathrm{Na}_{2} \mathrm{HPO}_{4} / \mathrm{NaH}_{2} \mathrm{PO}_{4}$, succinic acid/ $\mathrm{NaOH}$ or 2-amino-2-methyl-1,3-propanediol/ $\mathrm{HCl}$. The $\mathrm{pH}$ and $\mathrm{NaCl}(0-5 \%)$ ranges for growth were determined after 5 days of incubation at $32{ }^{\circ} \mathrm{C}$ in RCM. The temperature range for growth $\left(5-50{ }^{\circ} \mathrm{C}\right)$ was also determined. Growth was checked by monitoring optical density at $595 \mathrm{~nm}$ (Bio-Rad). Motility was observed in a Hungate tube containing $0.4 \%$ semi-solid agar. The cell-wall sugar and diaminopimelic acid in cell-wall hydrolysates were analysed by using solvent systems as described by Komagata \& Suzuki (1987).

Colonies of strain SL206 ${ }^{\mathrm{T}}$ cultivated on RCM agar were circular (approx. $1.0-1.5 \mathrm{~mm}$ in diameter), entire, convex and white or ivory. Cells were Gram-positive, strictly anaerobic and straight or slightly curved rods (1.0$1.3 \times 3.5-4.5 \mu \mathrm{m})$. Cells were motile with flagella that were primarily peritrichately arranged. Oval endospores were observed in a terminal position (Fig. 1a). Electron micrographs of thin sections of cells showed that the cytoplasmic membrane of the strain was surrounded by a peptidoglycan layer and an outer layer (Fig. 1b). Cells grew at $20-40{ }^{\circ} \mathrm{C}$ and at $\mathrm{pH}$ 5.5-9.0. Optimal growth was observed at $37{ }^{\circ} \mathrm{C}$ and $\mathrm{pH}$ 7.0. No growth occurred with greater than $3.0 \%$ $(\mathrm{w} / \mathrm{v}) \mathrm{NaCl}$.

The cell wall of strain SL206 ${ }^{\mathrm{T}}$ contained meso-diaminopimelic acid; wall sugars were glucose, rhamnose and mannose. In contrast, C. pasteurianum KCTC $1674^{\mathrm{T}}$ contained glucose, rhamnose, mannose and galactose, and C. acidisoli KCTC $5384^{\mathrm{T}}$ contained glucose, rhamnose and galactose. Cell wall sugars of strain $\mathrm{SL}_{206^{\mathrm{T}}}$ were significantly different from those of closely related species. Strain SL206 ${ }^{\mathrm{T}}$ was similar to the most closesly related species with respect to fatty acid profile, utilization of glucose, sucrose, maltose and mannose (Heyndrickx et al., 1991; Holdeman et al., 1977), and nitrogen-fixing activity in nitrogen-free media (Kasap \& Chen, 2005; Kuhner et al., 2000). However, it differed from the related species in certain phenotypic characteristics such as enzyme reaction and cell wall sugar composition. Detailed phenotypic characteristics of strain SL206 ${ }^{\mathrm{T}}$ are reported in Table 1 and the species description.

The nearly complete $16 \mathrm{~S}$ rRNA gene sequence ( $1347 \mathrm{bp}$ ) for strain SL206 ${ }^{\mathrm{T}}$ was determined according to Chang et al. (2002). The resulting sequence was aligned manually against sequences obtained from the GenBank database. Phylogenetic trees were inferred by using the neighbourjoining (Saitou \& Nei, 1987), Fitch-Margoliash (Fitch \& Margoliash, 1967) and maximum-parsimony (Fitch, 1971) methods. Evolutionary distance matrices for the neighbourjoining and Fitch-Margoliash methods were generated according to the model of Jukes \& Cantor (1969). The PHYLIP package (Felsenstein, 1993) was used for all analyses. The tree topology was evaluated by bootstrap analyses (Felsenstein, 1985) of the neighbour-joining methods based on 1000 resamplings.

A preliminary comparison of the $16 \mathrm{~S}$ rRNA gene sequence for strain SL206 ${ }^{\mathrm{T}}$ was performed by an initial BLAST search
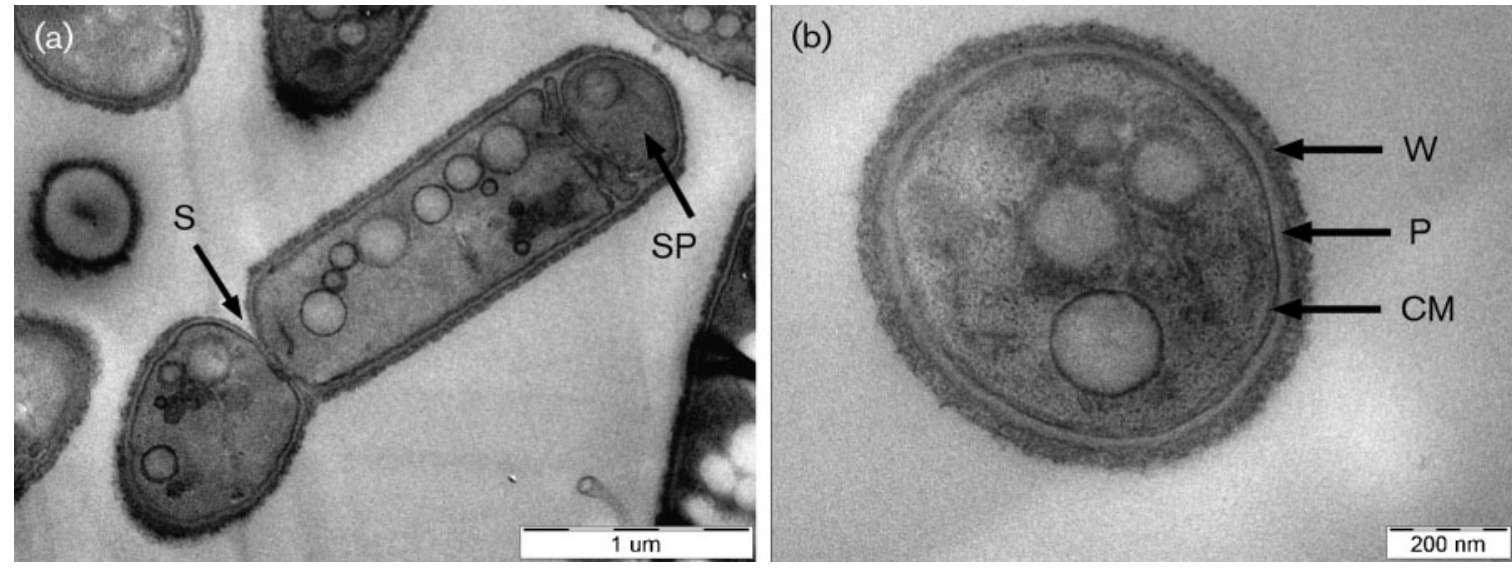

Fig. 1. Transmission electron micrographs of thin sections of strain SL206 ${ }^{\top}$ cells showing (a) cell division (bar, $\left.1 \mu \mathrm{m}\right)$ and (b) Gram-positive-type cell wall (bar, 200 nm). CM, cell membrane; P, peptidoglycan layer; S, septum; SP, spore; W, outer layer. 
Table 1. Differential physiological characteristics of strain $\mathrm{SL}^{206}{ }^{\top}$ and closely related species of the genus Clostridium

Strains: 1, SL206 ${ }^{\mathrm{T}}$; 2, C. pasteurianum KCTC $1674^{\mathrm{T}}$; 3, C. acidisoli KCTC $5384^{\mathrm{T}}$. + , Positive; -, negative; w, weakly positive. Data from this study.

\begin{tabular}{|c|c|c|c|}
\hline Characteristic & 1 & 2 & 3 \\
\hline $\begin{array}{l}\text { Growth temperature } \\
\text { range (optimum) }{ }^{\circ} \mathrm{C}\end{array}$ & $\begin{array}{c}20-40 \\
(37)\end{array}$ & $\begin{array}{r}25-45 \\
(32)\end{array}$ & $\begin{array}{l}5-37 \\
(25-30)\end{array}$ \\
\hline $\begin{array}{l}\text { Growth } \mathrm{pH} \text { range } \\
\text { (optimum) }\end{array}$ & $\begin{array}{c}5.5-9.0 \\
(7.0)\end{array}$ & $\begin{array}{c}4.7-7.5 \\
(7.0)\end{array}$ & $\begin{array}{l}4.0-7.0 \\
(4.0-6.5)\end{array}$ \\
\hline Growth in $3 \%(\mathrm{w} / \mathrm{v}) \mathrm{NaCl}$ & - & + & - \\
\hline Cell wall sugar* & $\mathrm{R}, \mathrm{M}, \mathrm{Gc}$ & $\mathrm{R}, \mathrm{M}, \mathrm{Gc}, \mathrm{Gl}$ & $\mathrm{R}, \mathrm{Gc}, \mathrm{Gl}$ \\
\hline Nitrogen-fixation & + & + & - \\
\hline DNA G $+\mathrm{C}$ content $(\mathrm{mol} \%)$ & 31.1 & $26-28$ & 30.7 \\
\hline \multicolumn{4}{|l|}{ API $20 \mathrm{~A}$} \\
\hline D-Mannitol & - & + & + \\
\hline Lactose & - & + & + \\
\hline Salicin & - & + & + \\
\hline D-Xylose & - & + & + \\
\hline L-Arabinose & - & + & + \\
\hline Aesculin & - & - & + \\
\hline Glycerol & - & + & + \\
\hline Cellobiose & - & + & + \\
\hline Melezitose & - & + & + \\
\hline D-Sorbitol & - & + & + \\
\hline D-Rhamnose & - & + & + \\
\hline Trehalose & - & + & - \\
\hline \multicolumn{4}{|l|}{ API $32 \mathrm{~A}$ or $\mathrm{ZYM}$} \\
\hline$\alpha$-Galactosidase & + & - & - \\
\hline$\beta$-Galactosidase & - & - & + \\
\hline$\beta$-Glucosidase & - & - & + \\
\hline Glutamic acid decarboxylase & + & - & - \\
\hline Acid phosphatase & - & - & + \\
\hline Akaline phosphatase & - & - & $\mathrm{W}$ \\
\hline
\end{tabular}

${ }^{\star} \mathrm{R}$, Rhamnose; M, mannose; Gc, glucose; Gl, galactose.

against the GenBank database. The result clearly indicated that the isolate belonged to cluster I of the genus Clostridium; this cluster contains the type species of the genus, C. butyricum. Aligned sequences of strain SL206 ${ }^{\mathrm{T}}$ and members of cluster I of this genus were analysed on the basis of the secondary structure of the bacterial 16S rRNA gene. Phylogenetically, strain SL206 ${ }^{\mathrm{T}}$ was closest to C. pasteurianum ATCC $6013^{\mathrm{T}}$. The results of comprehensive phylogenetic analyses are summarized in Fig. 2. The strain formed a monophyletic clade with the type strain of $C$. pasteurianum (M23930). The clade was confirmed by other treeing algorithms and was supported by a $97 \%$ bootstrap value. In the pairwise comparison of $16 \mathrm{~S}$ rRNA gene similarities, the closest phylogenetic relatives to strain SL206 ${ }^{\mathrm{T}}$ were $C$. pasteurianum (98.6\%), C. acidisoli (97.8\%) and Clostridium akagii $(96.9 \%)$. Strain SL206 ${ }^{\mathrm{T}}$ and its closest relatives exhibited more than $97 \%$ sequence similarity. Therefore, we examined their genomic relatedness using the spectrophotometric DNA-DNA reassociation method.
DNA-DNA hybridization was performed, as described previously (Chang et al., 2008), with photobiotin-labelled probes at $45{ }^{\circ} \mathrm{C}$ using a Fluoroskan Ascent Fluorescent plate reader (Thermo Life Science). Three replicates of each sample were tested. DNA-DNA hybridization values between strain SL206 ${ }^{\mathrm{T}}$ and strains C. pasteurianum KCTC $1674^{\mathrm{T}}$ and C. acidisoli KCTC $5384^{\mathrm{T}}$ were 59.5 and $53.2 \%$, respectively. These values were moderate but below the suggested threshold value for species delineation (Wayne et al., 1987). These values indicate that strain SL206 ${ }^{\mathrm{T}}$ represents a novel species that is distinct from $C$. pasteurianum and C. acidisoli.

To determine the DNA G $+\mathrm{C}(\mathrm{mol} \%)$ content, DNA was prepared according to Chang et al. (2002) and analysed by reversed-phase HPLC as described by Tamaoka \& Komagata (1984). The relative values were calculated by using Escherichia coli KCTC $2441^{\mathrm{T}}$ DNA as the standard. The DNA G + C content of strain SL206 ${ }^{\mathrm{T}}$ was $31.1 \mathrm{~mol} \%$. Although this value was a little higher than those reported for C. pasteurianum (26-28 mol\%; Holdeman et al., 1977) and C. acidisoli (30.7 mol\%; Kuhner et al., 2000), its taxonomic position suggests that strain SL206 ${ }^{\mathrm{T}}$ represents a member of cluster I and the low-G $+\mathrm{C}$ Gram-positive bacteria of the order Clostridiales (Wiegel et al., 2006).

Cellular fatty acid patterns of cells grown on PYG medium (DSMZ medium 104) at $37{ }^{\circ} \mathrm{C}$ were determined after $24 \mathrm{~h}$ by extracting and analysing the fatty acid methyl esters (FAMEs) according to a standard protocol (Sherlock Microbial Identification System; MIDI). The FAMEs were separated with an automated GC system (model 6890N and 7683 autosampler; Agilent) and identified by using the Microbial Identification software package (Moore library).

Cellular fatty acid patterns for the novel strain were examined and compared with the patterns of $C$. pasteurianum KCTC $1674^{\mathrm{T}}$ and C. acidisoli KCTC $5384^{\mathrm{T}}$ (Table 2). In all three strains, $C_{16: 0}, C_{18: 1} \omega 9 c$ and summed feature 10 (containing $\mathrm{C}_{18: 1} \omega 11 \mathrm{c} / 9 \mathrm{t} / 6 \mathrm{t}$ ) were the most common fatty acids, comprising approximately $75-86 \%$ of total extracted lipids. The major fatty acids for strain $\mathrm{SL}_{206}{ }^{\mathrm{T}}\left(\mathrm{C}_{16: 0}\right.$, $\mathrm{C}_{18: 1}(\omega 9 c)$ were similar to those of other species, whereas the strain differed from this group by the presence of $\mathrm{C}_{18: 0}$ 12- $\mathrm{OH}$ and the absence of $\mathrm{C}_{16: 0}$ DMA (dimethyl acetate), $\mathrm{C}_{18: 1} \omega 9 c$ DMA and $\mathrm{C}_{19: 0}$ cyclo 9,10 DMA.

For detection of end-products from glucose metabolism, strain SL206 ${ }^{\mathrm{T}}$ was cultivated in PY basal medium (DSMZ medium 104 without glucose and Tween 80 , and with only $1 \mathrm{~g}$ yeast extract $\mathrm{l}^{-1}$ ) at $37{ }^{\circ} \mathrm{C}$ for $24 \mathrm{~h}$. Prior to cultivation, pre-sterilized glucose solution was added to the medium to a final concentration of $20 \mathrm{mM}$. All cultivations were carried out in $50 \mathrm{ml}$ serum vials (working volume of $20 \mathrm{ml})$ under an atmosphere of $\mathrm{N}_{2} / \mathrm{CO}_{2}(85: 15, \mathrm{v} / \mathrm{v})$. Fermentation end-products were analysed by GC (Varian 3400 GC; Varian Associates) equipped with a flameionization detector and CP wax 52 CB column, according to methods described by Holdeman et al. (1977) and Steer et al. (2001). 


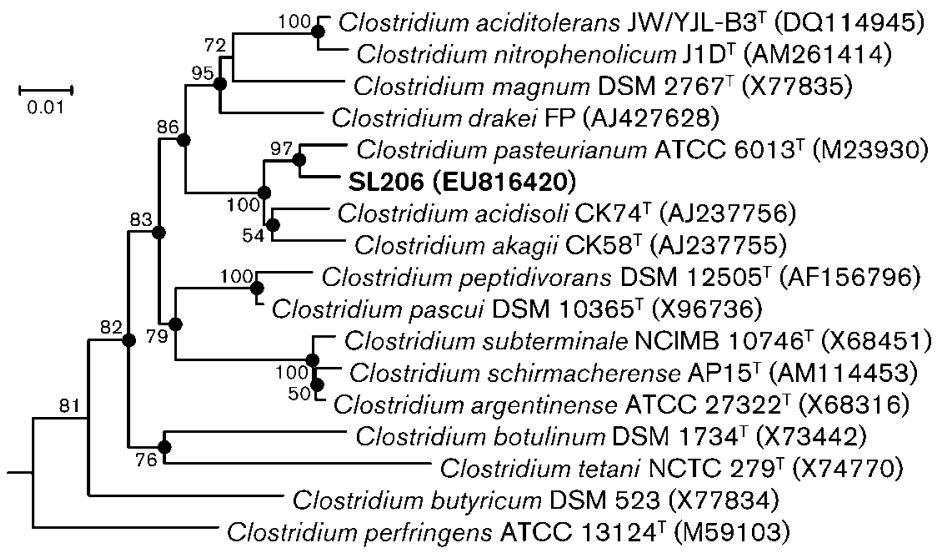

Fig. 2. Neighbour-joining phylogenetic tree based on 16S rRNA gene sequences (1347 bp) showing relationships of strain $\mathrm{SL206}^{\top}$ within the genus Clostridium. Bootstrap values are calculated from 1000 replications and values $>50 \%$ are shown at branch points. Filled circles indicate that the corresponding nodes were also recovered in the tree generated with the maximumparsimony algorithm. Bar, 0.01 changes per nucleotide position.

Nitrogen-fixing cultures were grown on a nitrogen-free medium, as described by Kasap \& Chen (2005), consisting of: sucrose, $30 \mathrm{~g} ; \mathrm{K}_{2} \mathrm{HPO}_{4}, 0.69 \mathrm{~g} ; \mathrm{Na}_{2} \mathrm{SO}_{4} \cdot 10 \mathrm{H}_{2} \mathrm{O}, 0.19 \mathrm{~g}$; mineral solution, $1 \mathrm{ml}$ (KCTC medium no. 650); $\mathrm{CaCO}_{3}$, $5 \mathrm{~g}$ and resazurin $1 \mathrm{mg}$ (per litre of distilled water). Cultures were grown at $32{ }^{\circ} \mathrm{C}$ under $\mathrm{N}_{2}$ in rubberstoppered $160 \mathrm{ml}$ serum bottles containing $50 \mathrm{ml}$ of medium. Acetylene-reduction assay was used to measure nitrogenase activity, as described by Lee et al. (2002), by gas chromatography (Shimadzu 17A) with a flame-ionization detector (FID). The head space of cultures was replaced by argon gas and $10 \%$ acetylene gas was added. Tubes were incubated at $32{ }^{\circ} \mathrm{C}$ for $1 \mathrm{~h}$ with shaking, and then $300 \mu \mathrm{l}$ sample was used for GC analysis.

Analysis of fermentation end-products from glucose metabolism showed that acetate, butyrate, acids, abundant

Table 2. Cellular fatty acid compositions of strain SL206 ${ }^{\top}$ and closely related species of the genus Clostridium

Strains: 1, SL206 ${ }^{\mathrm{T}}$; 2, C. pasteurianum KCTC $1674^{\mathrm{T}}$; 3, C. acidisoli KCTC $5384^{\mathrm{T}}$. Values are percentages of total fatty acids detected. -, Not detected; DMA, dimethyl acetate. Data from this study.

\begin{tabular}{|lccc|}
\hline Fatty acid & $\mathbf{1}$ & $\mathbf{2}$ & $\mathbf{3}$ \\
\hline $\mathrm{C}_{14: 0}$ & 2.6 & 2.5 & 2.8 \\
$\mathrm{C}_{16: 1} \omega 9 c$ & 4.6 & 5.7 & 5.5 \\
$\mathrm{C}_{16: 0}$ & 31.8 & 29.7 & 31.6 \\
$\mathrm{C}_{16: 1} \omega 9 c$ DMA & 2.3 & - & 1.7 \\
$\mathrm{C}_{16: 0}$ DMA & - & - & 1.9 \\
$\mathrm{C}_{17: 0}$ cyclo DMA & 3.0 & - & 5.7 \\
$\mathrm{C}_{18: 1} \omega 9 c$ & 38.0 & 44.9 & 34.2 \\
$\mathrm{C}_{18: 0}$ & 5.8 & 6.3 & 3.4 \\
$\mathrm{C}_{18: 1} \omega 9 c$ DMA & - & - & 3.0 \\
$\mathrm{C}_{18: 0} 12-\mathrm{OH}$ & 2.9 & - & - \\
$\mathrm{C}_{19: 0}$ cyclo 9,10 DMA & - & - & 1.2 \\
Summed feature $10^{*}$ & 9.0 & 11.0 & 8.9 \\
\hline
\end{tabular}

${ }^{\star}$ Fatty acids that could not be separated by GC using the Microbial Identification System (Microbial ID) software were considered summed features. Summed feature 10 contains $C_{18: 1} \omega 11 c / 9 t / 6 t$.
$\mathrm{CO}_{2}$ and $\mathrm{H}_{2}$ were formed by strain $\mathrm{SL} 206^{\mathrm{T}}$, whereas lactate was not detected. Ethanol was produced. Pyruvate was converted principally to acetate, butyrate, $\mathrm{CO}_{2}$ and $\mathrm{H}_{2}$; lactate was not utilized (Wiegel et al., 2006).

Acetylene-reduction assay was used to measure whole-cell nitrogenase activity for strain SL206 ${ }^{\mathrm{T}}$. When grown on medium in the presence of molybdenum, the strain reduced acetylene to ethylene (approx. $0.51 \mathrm{mg} \mathrm{l}^{-1}$ ). C. pasteurianum KCTC $1674^{\mathrm{T}}$ also showed nitrogenase activity (approx. $0.64 \mathrm{mg}$ ethylene $\mathrm{l}^{-1}$ ), but $C$. acidisoli KCTC $5384^{\mathrm{T}}$ did not. No nitrogenase activity was evident in the absence of Mo. Molybdenum was essential for the biosynthesis and activity of the nitrogenase involved (Wiegel et al., 2006).

On the basis of its cell wall sugar composition, nitrogenase activity, fatty acid pattern, DNA G + C content (31.1 mol\%), DNA-DNA hybridization values $(<59.5 \%)$, 16S rRNA gene sequence analyses ( $<98.6 \%$ similarity), growth temperature and $\mathrm{pH}$ range, strain $\mathrm{SL} 206^{\mathrm{T}}$ can be differentiated from members of the genus Clostridium as a novel species, for which the name Clostridium arbusti sp. nov. is proposed.

\section{Description of Clostridium arbusti sp. nov.}

Clostridium arbusti (ar.bu'sti. L. gen. n. arbusti of an orchard, isolated from pear orchard soil).

Cells in RCM agar culture are Gram-staining-positive, straight to slightly curved rods, $1.0-1.3 \times 3.5-4.5 \mu \mathrm{m}$, occurring singly or in pairs. Motile cells are peritrichous. Spores are oval, terminal and do not swell the cell. Cell walls contain meso-diaminopimelic acid; wall sugars are glucose, rhamnose and mannose. Surface colonies on RCM agar plates are $1-1.5 \mathrm{~mm}$ in diameter, circular to irregular, low convex, translucent to semiopaque, white or ivory and shiny with a smooth or erose margin and an entire internal structure. Cultures in PYG broth are turbid with a smooth sediment and have a $\mathrm{pH}$ of 5.0-5.2 after incubation for 5 days. The optimum temperature for growth is $37^{\circ} \mathrm{C}$. Strains grow nearly as well at $35^{\circ} \mathrm{C}$, moderately well at $32{ }^{\circ} \mathrm{C}$ and poorly if at all at $40{ }^{\circ} \mathrm{C}$. Growth is stimulated by fermentable carbohydrate but inhibited by $3.0 \% \mathrm{NaCl}$ or a 
$\mathrm{pH}$ of 9.0. Growth occurs in synthetic medium. Abundant gas is detected in RCM and PYG deep agar cultures. Negative API 20A reactions for oxidase, catalase and acid production from L-rhamnose, sucrose, trehalose, D-xylose, melezitose, salicin and D-sorbitol; positive reactions for acid production from D-glucose, sucrose, maltose, Dmannose and raffinose. Positive Rapid ID 32A reactions for $\alpha$-galactosidase, $\alpha$-glucosidase and glutamic acid decarboxylase. Positive API ZYM reactions for naphtholAS-BI-phosphohydrolase, $\alpha$-galactosidase, $\alpha$-glucosidase; negative reactions for acid phosphatase, alkaline phosphatase, esterase, esterase lipase, lipase, leucine arylamidase, valine arylamidase, cystine arylamidase, trypsin, $\alpha$-chymotrypsin, $\beta$-galactosidase, $\beta$-glucuronidase, $\beta$-glucosidase, $N$-acetyl- $\beta$-glucosaminidase, $\alpha$-mannosidase and $\alpha$-fucosidase. Atmospheric $\mathrm{N}_{2}$ is fixed; molybdenum is essential for biosynthesis and activity of the nitrogenase involved. Cellular fatty acids include mainly the straight chain $\mathrm{C}_{16: 0}$, monounsaturated $\mathrm{C}_{18: 0} \omega 9 \mathrm{c}$ and summed feature 10 (containing $\mathrm{C}_{18: 1} \omega 11 \mathrm{c} / 9 \mathrm{t} / 6 t$ ). The DNA G $+\mathrm{C}$ content of the type strain is $31.1 \mathrm{~mol} \%$. Products in PYG broth cultures include butyric and acetic acids; abundant $\mathrm{CO}_{2}$ and $\mathrm{H}_{2}$ are detected. Ethanol is produced. Pyruvate is converted principally to acetate, butyrate, $\mathrm{CO}_{2}$ and $\mathrm{H}_{2}$; lactate is not utilized.

The type strain is $\mathrm{SL}_{206}{ }^{\mathrm{T}}\left(=\mathrm{KCTC} 5449^{\mathrm{T}}=\mathrm{JCM} 14858^{\mathrm{T}}\right)$, isolated from soil samples from a pear orchard in Daejeon, Republic of Korea.

\section{Acknowledgements}

We are grateful to Dr Jean P. Euzéby (Society for Systematic and Veterinary Bacteriology, France) for his advice on nomenclatural queries and Dr Jeong Kug Lee (Dept. Life Science, Sogang University, Korea) for his courtesy of performing the acetylene reduction analysis. This work was supported by the Korea Science and Engineering Foundation and the KRIBB Research Initiative Program funded by the Ministry of Education, Science and Technology (MEST), Republic of Korea (grants NMC0300837 and 2009-0080150).

\section{References}

Chang, Y.-H., Han, J., Chun, J., Lee, K. C., Rhee, M.-S., Kim, Y.-B. \& Bae, K. S. (2002). Comamonas koreensis sp. nov., a non-motile species from wetland in Woopo, Korea. Int J Syst Evol Microbiol 52, 377-381.

Chang, Y.-H., Jung, M. Y., Park, I.-S. \& Oh, H.-M. (2008). Sporolactobacillus vineae sp. nov., a spore-forming lactic acid bacterium isolated from vineyard soil. Int J Syst Evol Microbiol 58, 2316-2320.

Collins, M. D., Lawson, P. A., Willems, A., Cordoba, J. J., FernandezGarayzabal, J., Garcia, P., Cai, J., Hippe, H. \& Farrow, J. A. (1994). The phylogeny of the genus Clostridium: proposal of five new genera and eleven new species combinations. Int J Syst Bacteriol 44, 812-826.

Felsenstein, J. (1985). Confidence limits on phylogenies: an approach using the bootstrap. Evolution 39, 783-791.
Felsenstein, J. (1993). PHYLIP (phylogeny inference package), version 3.5c. Distributed by the author. Department of Genome Sciences, University of Washington, Seattle, USA.

Fitch, W. M. (1971). Toward defining the course of evolution: minimum change for a specific tree topology. Syst Zool 20, 406-416.

Fitch, W. M. \& Margoliash, E. (1967). Construction of phylogenetic trees. Science 155, 279-284.

Heyndrickx, M., De Vos, P. \& De Ley, J. (1991). Fermentation characteristics of Clostridium pasteurianum LMG 3285 grown on glucose and mannitol. J Appl Bacteriol 70, 52-58.

Holdeman, L. V. \& Cato, E. P. \&Moore, W. E. C. (1977). Anaerobe Laboratory Manual, 4th edn. Blacksburg, VA: Virginia Polytechnic Institute and State University.

Jeong, H., Yi, H., Sekiguchi, Y., Muramatsu, M., Kamagata, Y. \& Chun, J. (2004). Clostridium jejuense sp. nov., isolated from soil. Int J Syst Evol Microbiol 54, 1465-1468.

Jukes, T. H. \& Cantor, C. R. (1969). Evolution of protein molecules. In Mammalian Protein Metabolism, vol. 3, pp. 21-132. Edited by $\mathrm{H}$. N. Munro. New York: Academic Press.

Kasap, M. \& Chen, J.-S. (2005). Clostridium pasteurianum W5 synthesizes two NifH-related polypeptides under nitrogen-fixing conditions. Microbiology 151, 2353-2362.

Kim, S., Jeong, H. \& Chun, J. (2006). Clostridium ganghwense sp. nov., isolated from tidal flat sediment. Int J Syst Evol Microbiol 56, 691-693.

Kim, S., Jeong, H. \& Chun, J. (2007). Clostridium aestuarii sp. nov., from tidal flat sediment. Int J Syst Evol Microbiol 57, 1315-1317.

Komagata, K. \& Suzuki, K. (1987). Lipid and cell-wall analysis in bacterial systematics. Methods Microbiol 19, 161-207.

Kuhner, C. H., Matthies, C., Acker, G., Schmittroth, M., Gößner, A. S. \& Drake, H. L. (2000). Clostridium akagii sp. nov. and Clostridium acidisoli sp. nov.: acid-tolerant, $\mathrm{N}_{2}$-fixing clostridia isolated from acidic forest soil and litter. Int J Syst Evol Microbiol 50, 873-881.

Lee, I.-H., Park, J. Y., Kho, D. H., Kim, M.-S. \& Lee, J. K. (2002). Reductive effect of $\mathrm{H}_{2}$ uptake and poly- $\beta$-hydroxybutyrate formation on nitrogenase-mediated $\mathrm{H}_{2}$ accumulation of Rhodobacter sphaeroides according to light intensity. Appl Microbiol Biotechnol 60, 147-153.

Lee, Y.-J., Romanek, C. S. \& Wiegel, J. (2007). Clostridium aciditolerans sp. nov., an acid-tolerant spore-forming anaerobic bacterium from constructed wetland sediment. Int J Syst Evol Microbiol 57, 311-315.

Saitou, N. \& Nei, M. (1987). The neighbor-joining method: a new method for reconstructing phylogenetic trees. Mol Biol Evol 4, 406-425.

Steer, T., Collins, M. D., Gibson, G. R., Hippe, H. \& Lawson, P. A. (2001). Clostridium hathewayi sp. nov., from human faeces. Syst Appl Microbiol 24, 353-357.

Tamaoka, J. \& Komagata, K. (1984). Determination of DNA base composition by reversed-phase high-performance liquid chromatography. FEMS Microbiol Lett 25, 125-128.

Wayne, L. G., Brenner, D. J., Colwell, R. R., Grimont, P. A. D., Kandler, O., Krichevsky, M. I., Moore, L. H., Moore, W. E. C., Murray, R. G. E. \& other authors (1987). International Committee on Systematic Bacteriology. Report of the ad hoc committee on reconciliation of approaches to bacterial systematics. Int J Syst Bacteriol 37, 463-464.

Wiegel, J., Tanner, R. \& Rainey, F. A. (2006). An introduction to the family Clostridiaceae. In The Prokaryotes: a Handbook on the Biology of Bacteria, 3rd edn, vol. 4, pp. 654-678. Edited by M. Dworkin, S. Falkow, E. Rosenberg, K. H. Schleifer \& E. Stackebrandt. New York: Springer. 